\title{
A Range Extension of the Atlantic Silverside, Menidia menidia, to Coastal Waters of Southwestern Newfoundland
}

\author{
Philip S. Sargent ${ }^{1}$, D. A. Methven ${ }^{2}$, Robert G. Hooper ${ }^{3}$, and Cynthia H. McKenzie ${ }^{4}$ \\ ${ }^{1}$ Ocean Sciences Centre, Memorial University of Newfoundland, St. John's, Newfoundland and Labrador A1C 5S7 Canada \\ ${ }^{2}$ Department of Biology and Canadian Rivers Institute, University of New Brunswick, Saint John, New Brunswick E2L 4L5 \\ Canada \\ ${ }^{3}$ Department of Biology, Memorial University of Newfoundland, St. John's, Newfoundland and Labrador A1B 3X9 Canada \\ ${ }^{4}$ Ecological Sciences Section, Science Branch, Fisheries and Oceans Canada, Northwest Atlantic Fisheries Centre, St. John's, \\ Newfoundland and Labrador A1C 5X1 Canada
}

Sargent, Philip S., D. A. Methven, Robert G. Hooper, and Cynthia H. McKenzie. 2008. A range extension of the Atlantic Silverside, Menidia menidia, to coastal waters of southwestern Newfoundland. Canadian Field-Naturalist 122(4): 338-344.

Previous literature documents Atlantic Silverside, Menidia menidia, as occurring from the southern Gulf of St. Lawrence to northeastern Florida. Beach seining in St. George's Bay, Newfoundland, revealed the presence of this species in coastal waters of southwestern Newfoundland. This is the first documented report of M. menidia in Newfoundland waters. This report extends the range of this species north of the Laurentian Channel, a significant biogeographic barrier to small coastal fishes. All M. menidia collected were young-of-the-year, less than $90 \mathrm{~mm}$ SL (Standard Length). These fish may be representative of a larger relict population originating from the Mid-Hypsithermal Interval (7000 years ago) that spawn in St. George's Bay and migrate offshore for winter. Alternatively, these M. menidia may be survivors of a more southern spawning population carried northward by ocean currents.

Key Words: Atlantic Silverside, Menidia menidia, species distribution, range extension, Newfoundland.

Beginning in autumn 2006, surveys were conducted along the coast of Newfoundland as part of the project "Early Detection and Monitoring of Aquatic Invasive Species in Newfoundland and Labrador in High Risk Areas". This project was part of the Government of Canada's Action Plan to Address the Threat of Aquatic Invasive Species (2005). Surveys were conducted collaboratively by representatives of the Federal Department of Fisheries and Oceans (DFO), Provincial Department of Fisheries and Aquaculture, and Memorial University's Ocean Sciences Centre. The objective was to determine the presence and abundance of non-native species in Newfoundland coastal waters, and whether these species pose ecological or economic threats in the province.

\section{Materials and Methods}

Surveys for this project included visual beach surveys, scuba surveys around public wharves, setting two or three baited crab pots from wharves, and one or more beach seines adjacent to wharves. One such survey was conducted on the southwest coast of Newfoundland in St. George's Bay on 18 October 2007. A scuba survey was taken at the public wharf in the community of St. George's $\left(48^{\circ} 25^{\prime} 49.4^{\prime \prime} \mathrm{N} ; 58^{\circ} 29^{\prime} 04.1^{\prime \prime} \mathrm{W}\right)$ and a beach seine was set just east of this wharf (4825'54.3"N; 58²8'54.4"W; Figure 1).

The scuba survey involved a visual survey of the wharf structure and surrounding habitat for non-native organisms. Habitat and environmental conditions of the area were noted. The beach seine used for this project was the same as that described in Laurel et al.
(2003) with the exception that a $10 \mathrm{~mm}$ stretched mesh liner was sewn into the bag of the net (excluding the cod end). The seine, deployed perpendicular to shore by a $4 \mathrm{~m}$ Mark II Zodiac, sampled more than $800 \mathrm{~m}^{2}$ of habitat from the substrate to $2 \mathrm{~m}$ into the water column (Laurel et al. 2003). The catch was transferred to a plastic commercial "fish box" $(80 \mathrm{~cm} \mathrm{~L} \times 47 \mathrm{~cm}$ $\mathrm{W} \times 30 \mathrm{~cm} \mathrm{H}$ ) with seawater and each species was identified, counted and returned alive to the seine site. Unidentified species were retained and preserved in plastic sample jars with $10 \%$ formalin added to seawater for later identification. Fish species were identified based on descriptions presented in Scott and Scott (1988) and Able and Fahay (1998).

\section{Results}

Fishes captured in the beach seine set in St. George's are listed in Table 1. Eight specimens of Atlantic Silverside, Menidia menidia (Linnaeus 1766; Figure 2), were captured, of which three were preserved for confirmation of species identification. Counts of dorsal and anal fin rays (Table 2) identified these specimens as $M$. menidia and distinguished them from $M$. beryllina.

In St. George's, shoreline substrate consisted primarily of gravel with Fucus sp. on small rocks near shore, and patches of Eelgrass, Zostera marina, further from shore. At $3 \mathrm{~m}$, approximately the maximum depth sampled by the beach seine, water temperature was $5^{\circ} \mathrm{C}$ and the upper $2 \mathrm{~m}$ was primarily freshwater with a distinct boundary layer, as observed during the scuba survey conducted at the public wharf. 


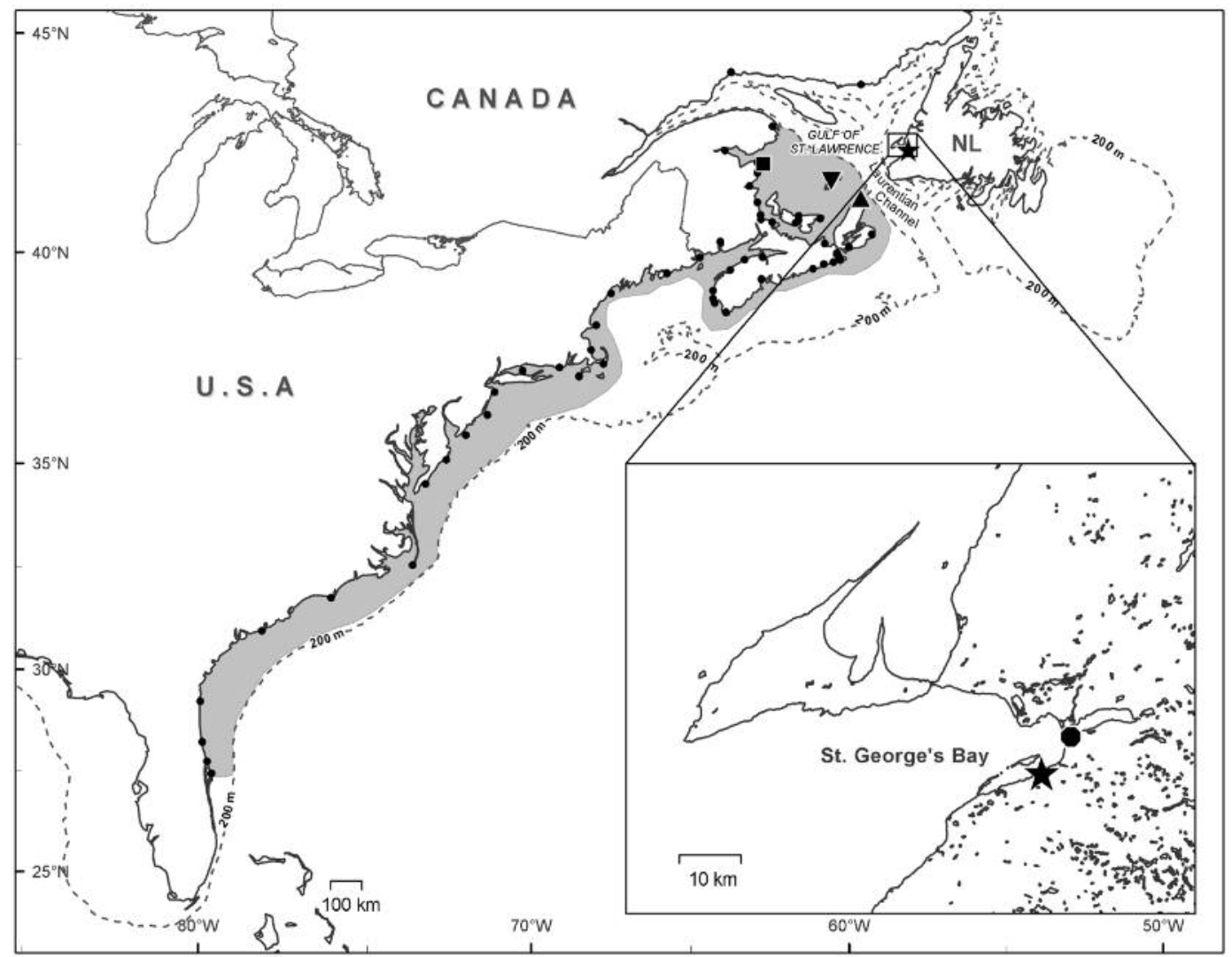

FIGURE 1. Map of Eastern North America. Shaded area indicates the current distributional range of Atlantic Silverside, Menidia menidia within the 100m isobath (excluding Georges Bank and the Scotian Shelf) based on data from the following sources: Cox 1921; Squires and Gorham 1967; Johnson 1975; Weinstein et al. 1980; Gilmurray and Daborn 1981; Conover and Murawski 1982; Jessop 1983; Johnston and Morse 1988; Moring 1990; Hanson and Courtenay 1995; DFO 2007; Thériault et al. 2006, 2007; O’Connor 2008; DFO-FSRS Inshore Ecosystem Project, unpublished data; S. Courtenay and P. Nellis, personal communications. - - Bay St. Lawrence, Cape Breton, Nova Scotia and - - Île du Havre aux Maisons, Magdalen Islands, Quebec; - the closest known reports of M. menidia to St. George's - Lamèque Bay, New Brunswick - the previous most northern literature report for M. menidia.

Insert is an expanded view of St. George's Bay. • - observations of M. menidia from the sources above; $\star-$ St. George's, where $M$. menidia specimens were captured in this study (48 $25^{\prime} 54.3^{\prime \prime N}$; $\left.58^{\circ} 28^{\prime} 54.4^{\prime \prime W}\right)$. • - Stephenville Crossing, where M. menidia were also captured $\left(48^{\circ} 29^{\prime} 06.20^{\prime \prime} \mathrm{N} ; 58^{\circ} 25^{\prime} 06.60^{\prime \prime} \mathrm{W}\right)$. Data points outside the shaded region (including those in St. George's Bay and the northern Gulf of St. Lawrence) indicate areas where breeding populations have yet to be confirmed.

The M. menidia specimens were deposited in The Rooms, Provincial Museum of Natural History Annex, 9 Bonaventure Avenue, P.O. Box 1800, Stn. C, St. John's, Newfoundland and Labrador A1C 5P9 Canada, under Catalogue \# PI-44.

\section{Discussion}

The Atlantic Silverside, Menidia menidia, is a schooling species common in brackish marshes, intertidal creeks, and estuaries along coastal waters of the western Atlantic from the southern Gulf of St. Lawrence to northeastern Florida during summer and au- tumn (Johnson 1975; Scott and Scott 1988; Collette and Klein-MacPhee 2002; Figure 2). Menidia menidia is most similar to Inland Silverside, M. beryllina, with which it co-occurs from southern Massachusetts to northeastern Florida (Johnson 1974). Counts of dorsal and anal fin rays (Table 2) distinguish these two species and identified the specimens collected in St. George's as M. menidia.

Menidia menidia is reported to be an annual species completing its life cycle in one year (Conover and Murawski 1982), although populations near its northern limit apparently have a larger proportion surviving 
TABLE 1. Fishes taken by beach seine at St. George's (48²5'54.3"N, 58²8'54.4"W) on 18 October 2007.

\begin{tabular}{llc}
\hline \hline Common Name & Species Name & Number Caught \\
\hline Sand Lance & Ammodytes sp. & 1 \\
Fourspine Stickleback & Apeltes quadracus & Many (not counted) \\
Threespine Stickleback & Gasterosteus aculeatus & Many (not counted) \\
Atlantic Tomcod & Microgadus tomcod & 26 \\
Atlantic Silverside & Menidia menidia & 8 \\
Sculpin (small) & Myoxocephalus sp. & 1 \\
Rainbow Smelt (juvenile) & Osmerus mordax & 1 \\
Winter Flounder & Pseudopleuronectes americanus & 2 \\
Cunner (juvenile) & Tautogolabrus adspersus & 16 \\
White Hake (juvenile) & Urophycis tenuis & 2 \\
\hline \hline
\end{tabular}

to age-2 than southern populations (Jessop 1983). Typically, adults move into estuaries and salt marshes in April or May (Jessop 1983), spawn between May and July (Needler 1940; Cadigan and Fell 1985), and decline in abundance during summer (Cadigan and Fell 1985) before returning to sea between July and October (Jessop 1983). Young-of-the-year begin migrating out of the estuary in September (Jessop 1983), by which time they can grow to $130 \mathrm{~mm}$ (total length) (Able and Fahay 1998), depending on location (e.g., Jessop 1983; Rountree and Able 1992; Able and Fahay 1998) and time of hatching (Cadigan and Fell 1985). This offshore migration may be in response to potential stressful and/or lethal water temperatures in shallow estuarine waters during winter (Conover and Murawski 1982). There are exceptions, however, as some individuals remain in estuaries throughout the winter (Collette and Klein-MacPhee 2002) and have even been taken through the ice in Malpeque Bay, Prince Edward Island (Needler 1940). Menidia menidia specimens retained from St. George's (Table 1) were some of the smallest captured in the beach seine, none of which measured more than $90 \mathrm{~mm}$ standard length (SL). Based on size and time of capture, specimens appear to be young-of-the-year that had yet to migrate to offshore waters or other parts of St. George's Bay, where they may overwinter. Young-of-the-year M. menidia in St. George's Bay suggests a local spawning population may occur nearby. Alternatively, M. menidia may be survivors from a more southern spawning population that were transported northward into St. George's Bay by ocean currents. Some species may be found in areas where they do not normally reproduce, being trans- ported as larvae by ocean currents (Markle et al. 1980; Steele 1983) or are summer visitors to Newfoundland waters (e.g., Atlantic Mackerel, Scomber scombrus, Bluefin Tuna, Thunnus thynnus, various sharks, and cetaceans) (Steele 1983).

Observed habitat and environmental conditions at St. George's were consistent with those preferred by Menidia menidia, as described in the literature. Salinity tolerances for this species range from $23.8-32.2 \%$ (Briggs and O'Connor 1971). Barker (1993) reported salinity in November 1992 at St. George's varied from $23.0 \%$ at the surface to $31.1 \%$ at $6 \mathrm{~m}$ depth. Menidia menidia occur closer to the bottom during daylight hours (Conover and Murawski 1982). Given that our seining was conducted during the day and that a distinct boundary was observed between the upper and lower saltwater layers, specimens collected at this site likely occurred in the lower, more saline layer. Specimens at St. George's were collected at $5^{\circ} \mathrm{C}$ water temperature. Temperature tolerances for this species range from $2.2-29.4^{\circ} \mathrm{C}$ (Briggs and O'Connor 1971) but occur most often between 2 and $6^{\circ} \mathrm{C}$ (Conover and Murawski 1982). Menidia menidia is found frequently in large numbers over sand, gravel (Scott and Scott 1988; Able and Fahay 1998), mud, or peat substrates (Collette and Klein-MacPhee 2002) at depths $<50 \mathrm{~m}$ (Conover and Murawski 1982). Young-of-the-year M. menidia are most abundant at depths of 1 to $3 \mathrm{~m}$ over sandy substrates and where complex habitat includes Eelgrass (Able and Fahay 1998; Mattila et al. 1999). Smaller individuals are found in larger proportions over vegetated habitats (Briggs and O'Connor 1971). Menidia menidia use estuarine environ-

TABLE 2. Standard lengths (mm) for M. menidia captured at St. George's (48²5'54.3"N, 58 $28^{\circ} 54.4^{\prime \prime}$ ) and their fin ray counts compared with differential characteristic fin ray counts (spines are Roman numerals; soft rays are Arabic numerals) of Menidia beryllina and M. menidia (as described by Able and Fahay 1998).

\begin{tabular}{lccccc}
\hline \hline Characteristic & M. beryllina & M. menidia & Specimen \#1 & Specimen \#2 & Specimen \#3 \\
\hline SL $(\mathrm{mm})$ & - & - & 51 & 56 & 58 \\
$1^{\text {st }}$ Dorsal & $\mathrm{V}$ & III - VII & VI & VI & VI \\
$2^{\text {nd }}$ Dorsal & $6-8$ & $7-11$ & 10 & 9 & 9 \\
Anal & $16-19$ & $19-29$ & 25 & 23 & 26 \\
\hline \hline
\end{tabular}




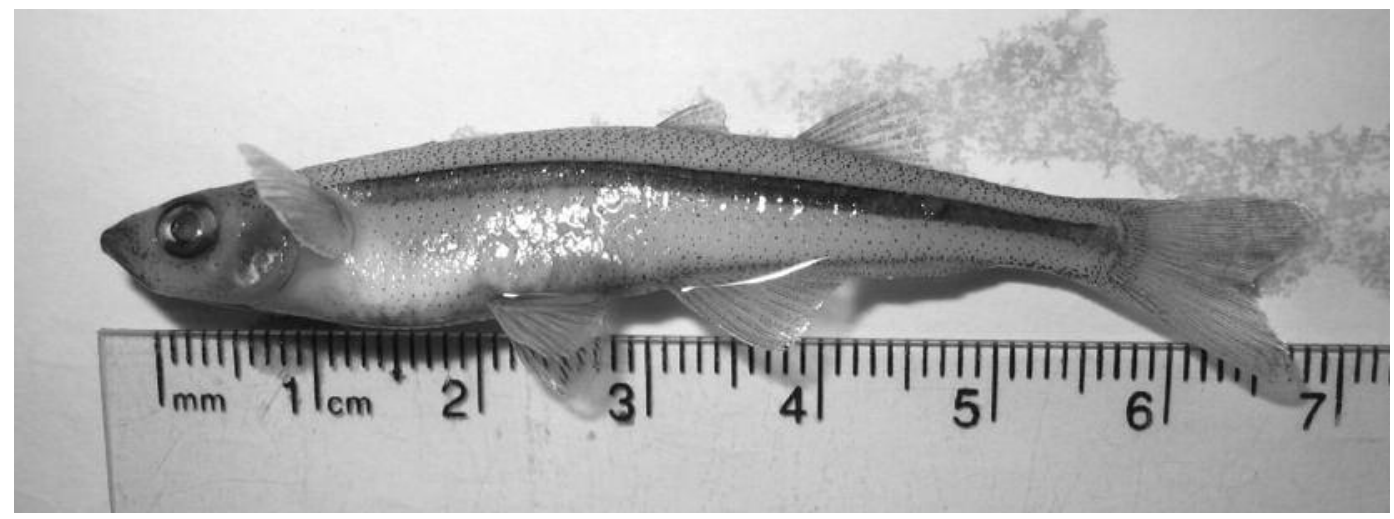

FIGURE 2. Atlantic Silverside, Menidia menidia, specimen collected from St. George's (48²5'54.3"N, 58 28'54.4"W) on 18 October 2007.

ments as spawning sites and feeding sites for juveniles and adults during warmer months (Cadigan and Fell 1985). Vegetated areas within these environments act as nurseries for young-of-the-year (Briggs and O'Connor 1971; Cadigan and Fell 1985; Able and Fahay 1998).

Collection of Menidia menidia in St. George's Bay, constitutes a range extension for this species to coastal Newfoundland waters that are northeast of the Laurentian Channel. The Laurentian Channel is $>400 \mathrm{~m}$ deep (Curry 2007) and is a geographic barrier separating the Scotian Shelf and Newfoundland Shelf marine ecosystems (Mahon et al. 1998). Though not a significant barrier to demersal fish species (Mahon et al. 1998), the Laurentian Channel may be a barrier to M. menidia that are confined to coastal waters (Scott and Scott 1988) to a maximum depth of $126 \mathrm{~m}$ (Conover and Murawski 1982).

In Atlantic Canada, Menidia menidia occurs throughout the southern Gulf of St. Lawrence region (Johnson 1975; Scott and Scott 1988; Collette and Klein-MacPhee 2002). Reports of M. menidia in this region include the Bay of Fundy (Squires and Gorham 1967; Gilmurray and Daborn 1981; Jessop 1983; O'Connor 2008), the east and southeast coasts of Nova Scotia (O'Connor 2008), off Cape Breton (Cox 1921; DFO 2007; DFO-Fishermen and Scientists Research Society (FSRS) Inshore Ecosystem Project, unpublished data), Prince Edward Island (Needler 1940; Johnston and Morse 1988; Thériault et al. 2006), Magdalen Islands (Cox 1921; P. Nellis, personal communication), along the Northumberland Strait (Thériault et al. 2006, 2007), Mirimichi Estuary (McKenzie 1959; Hanson and Courtenay 1995), Chaleur Bay (Thériault et al. 2006; S. Courtenay, personal communication) and Gaspé Bay (P. Nellis, personal communication). Along central and eastern coasts of Prince Edward Island there has even been a moderate commercial fishery since 1973, mostly for young-ofthe-year fish (Cairns 1997). The closest locations from St. George's (in linear distance), for which $M$. menidia has been previously reported, are Bay St. Lawrence (Deadman's Pond), Cape Breton, Nova Scotia (Cox 1921) $(220 \mathrm{~km})$ and Ile du Havre aux Maisons, Magdalen Islands, Quebec (Cox 1921) (265 km). In September 2008, small numbers of $M$. menidia were captured on the north side of the Gulf of St. Lawrence at Havre Bluff and Sept-Îles, Quebec (J-D. Dutil and P. Nellis, personal communications) (see Figure 1). All M. menidia from the northern Gulf of St. Lawrence were less than $60 \mathrm{~mm}$ total length (P. Nellis, unpublished data) and were likely juveniles. Menidia menidia were not observed at sites surveyed along the St. Lawrence River (P. Nellis, personal communication).

Menidia menidia has not been previously reported from coastal Newfoundland (Squires 1951; Scott and Crossman 1964; Templeman 1966; Gregory et al. 1997; Methven et al. 2001; I. Bradbury, personal communication) and Labrador (Backus 1957; Wroblewski et al. 2007). There are no records of specimens in the Newfoundland Provincial Museum of Natural History (R. Batten, personal communication) other than the three specimens deposited from this study. Johnson (1975) did state that M. menidia is found as far north as Newfoundland but provided no supporting data. Menidia menidia were captured by beach seine at Stephenville Crossing ( $\left.48^{\circ} 29^{\prime} 13.5^{\prime \prime} \mathrm{N}, 58^{\circ} 25^{\prime} 6^{\prime \prime} \mathrm{W}\right)$, less than $10 \mathrm{~km}$ from the seine site in St. George's, on 11 July 1973 (R. Hooper, unpublished data) but this information has not been reported until now. Subsequent beach seining at Stephenville Crossing $\left(48^{\circ} 29^{\prime} 06.20^{\prime \prime} \mathrm{N}\right.$, $58^{\circ} 25^{\prime} 06.60^{\prime \prime} \mathrm{W}$ ) on 7 September 2009 , resulted in 24 juvenile M. menidia (37 - $66 \mathrm{~mm} \mathrm{SL}$ ) being collected in approximately the same area R. Hooper collected them 36 years earlier. The northeast portion of St. George's Bay may therefore contain a previously undescribed spawning population. 
Species distributions are often disjunct and discontinuous in coastal areas from Labrador to southern New England (Bousfield and Thomas 1975; Hooper et al. 2002). Warm-water species typically require relatively high water temperatures for reproduction and/or growth and reproduce in late spring and summer (Bousfield and Thomas 1975). As a result, many warm-water species have restricted distributions in Atlantic Canada (Bousfield and Thomas 1975; Steele 1983; Hooper et al. 2002), which appears consistent with Menidia menidia (Needler 1940; Cadigan and Fell 1985). As explained by Bousfield and Thomas (1975), during the Mid-Hypsithermal period (7000 $\mathrm{BP}$ ), mean water temperatures were $2.5^{\circ} \mathrm{C}$ higher than those today, and warm-water fauna distributions were continuous throughout the Gulf of St. Lawrence to New England. Furthermore, through to the Post-Hypsithermal period (3000 years ago), as sea levels continued to rise, outer coastal margins sank and shorelines rose, warm-water and coastal marine fauna became isolated from populations in the south. Current warm-water regions are restricted to the southern portion of the Gulf of St. Lawrence, the head of the Bay of Fundy, and south of Cape Cod, with pockets in western Nova Scotia, the Magdalen shallows, and southwestern Newfoundland (Bousfield and Thomas 1975; Steele 1983).

Global climate fluctuations have resulted in changes to species distributions (Bousfield and Thomas 1975; Steele 1983; Hewitt 2000). Some species became extinct in parts of their range, dispersed into new regions, or survived in refugial areas, later expanding their distribution when climatic conditions again changed (Hewitt 2000). Menidia menidia in St. George's Bay may represent a relict population that existed throughout the Gulf of St. Lawrence region during the MidHypsithermal period. Alternatively, the presence of $M$. menidia in St. George's Bay may represent a new introduction or recent recolonization of this region. A phylogeographic study of $M$. menidia by analysis of mitochondrial DNA from specimens collected throughout Atlantic Canada may confirm the longterm separation of a refugial population or else a possible reintroduction of this species into southwestern Newfoundland.

At least two other fish species found in St. George's Bay have distributions limited primarily to the south and southwest coasts of Newfoundland. The Eastern Banded Killifish, Fundulus diaphonus diaphonus, has only seven known, highly restricted, populations in Newfoundland waters (Chippett 2003*). With the exception of the Indian Bay watershed population, all populations are located on the south and southwest coasts of Newfoundland (Chippett 2003*), one of which was reported at Stephenville Crossing, St. George's Bay (Squires 1951). Mummichog, Fundulus heteroclitus, a species very similar to Eastern Banded Killifish, are restricted to the southwest corner of Newfoundland, having been found in Piccadilly Bay,
Port au Port Bay; just north of Port aux Basques; and the head of St. George's Bay (Scott and Crossman 1964). Comparable population disjunctions are known for marine benthic algae (Hooper et al. 2002) and invertebrates (Bousfield and Thomas 1975).

Discovery of Menidia menidia in St. George's Bay supports the Early Detection and Monitoring of Aquatic Invasive Species in Newfoundland and Labrador in High Risk Areas in detecting macrofaunal species previously unknown to exist in this province. Since its inception in 2006, this project has discovered two invasive colonial tunicate species previously unrecorded in Newfoundland and Labrador waters. In 2006, Golden Star Tunicate, Botryllus schlosseri, was found in several areas of northern Placentia Bay (Callahan et al. 2007). In 2007, B. schlosseri was also found in Hermitage, Fortune Bay, and Violet Tunicate, Botrylloides violaceus, was discovered in Belloram, Fortune Bay (Callahan et al. 2009; McKenzie et al. 2009). Further, the expansion in distributional range of European Green Crab, Carcinus maenas, has also been monitored since its discovery in Placentia Bay by local fishermen in 2007 (C. H. McKenzie, unpublished data).

\section{Acknowledgments}

This work resulted from a project entitled "Early detection and monitoring of aquatic invasive species in Newfoundland and Labrador in high risk areas." Funding for fieldwork of this project was provided to C. McKenzie and D. Deibel by the Department of Fisheries and Oceans Aquatic Invasive Species Program as well as an NSERC Discovery Grant provided to D. Deibel and is part of the Government of Canada's Action Plan to Address the Threat of Aquatic Invasive Species (2005). We thank the following people for their assistance in conducting the western Newfoundland surveys: R. Boland, S. Kenny, D. Mouland, R. O'Donnell, and C. Vickers. Thank you to I. Bradbury, A. Bundy, S. Courtenay, J. -D. Dutil, P. King, and P. Nellis for information on the distribution of Atlantic Silverside in Atlantic Canada. Thanks also to T. Wells for constructing Figure 1 and to Danny Au for the Scott and Crossman (1964) reference.

Documents Cited (marked $*$ in the text)

Callahan, A. G, T. Baines, P. Sargent, R. Boland, R. O'Donnell, S. Kenny, C. Vickers, C. H. McKenzie and D. Deibel. 2007. Harbour survey for invasive species in Newfoundland, Canada. $5^{\text {th }}$ International Conference on Marine Bioinvasions, Cambridge, Massachusetts, USA, May 21-24, 2007.

Callahan, A. G., D. Deibel, J. Hall, M. Rise, and C. H. McKenzie. 2009. Determination of Cytochrome c Oxidase gene sequences of indigenous and non-indigenous ascidian tunicates of Newfoundland. $16^{\text {th }}$ International Conference on Aquatic Invasive Species, Montreal, Canada, April 1923, 2009.

Chippett, J. D. 2003. Update COSEWIC status report on the banded killifish Fundulus diaphonus, Newfoundland population in Canada. In COSEWIC assessment and update 
status report on the banded killifish Fundulus diaphanus in Canada. Committee on the Status of Endangered Wildlife in Canada. Ottawa. 21 pages.

McKenzie, C.H., G. Perry, T. Baines, D. Mouland, P. Sargent, R. O'Donnell, and D. Deibel. 2009b. The colonial violet tunicate, Botrylloides violaceus, in Belleoram Harbour, Fortune Bay, on the southern Newfoundland coastRapid response and mitigation strategy. $16^{\text {th }}$ International Conference on Aquatic Invasive Species, Montreal, Canada, April 19-23, 2009.

\section{Literature Cited}

Able, K. W., and M. P. Fahay. 1998. The first year in the life of estuarine fishes in the Middle Atlantic Bight. Rutgers University Press, New Brunswick, New Jersey. 342 pages.

Backus, R. H. 1957. The fishes of Labrador. Bulletin of the American Museum of Natural History 113: 275-333.

Barker, D. E. 1993. Evidence of chronic stress in winter flounder, Pleuronectes (= Pseudopleuronectes) americanus living adjacent to a pulp and paper mill in St. George's Bay, western Newfoundland. M.Sc. thesis, Memorial University of Newfoundland, St. John's, Newfoundland. 101 pages.

Briggs, P. T., and J. S. O'Connor. 1971. Comparison of shore-zone fishes over naturally vegetated and sand-filled bottoms in Great South Bay. New York Fish and Game Journal 18: 15-41.

Bousfield, E. L., and M. L. H. Thomas. 1975. Postglacial changes in distribution of littoral marine invertebrates in the Canadian Atlantic region. Proceedings of the Nova Scotian Institute of Science. Supplement 3: 47-60.

Cadigan, K. M., and P. E. Fell. 1985. Reproduction, growth and feeding habits of Menidia menidia (Atherinidae) in a tidal marsh-estuarine system in southern New England. Copeia 1985: 21-26.

Cairns, D. 1997. Prince Edward Island eels, gaspereau, silversides, and smelts. DFO Sock Status Report D3-18. 5 pages.

Collette, B., and G. Klein-MacPhee. (Editors). 2002. Bigelow and Schroeder's Fishes of the Gulf of Maine. Third Edition. Smithsonian Institution Press, Washington, DC. 748 pages.

Conover, D. O., and S. A. Murawski. 1982. Offshore winter migration of the Atlantic silverside, Menidia menidia. U.S. Fishery Bulletin 80: 145-150.

Cox, P. 1921. List of fishes collected in 1917 off the Cape Breton coast and the Magdalen Islands. Contributions to Canadian Biology 1918-1920 (11): 109-114.

Curry, R. A. 2007. Late glacial impacts on dispersal and colonization of Atlantic Canada and Maine by freshwater fishes. Quaternary Research 67: 225-233.

DFO. 2007. DFO/FSRS Inshore Ecosystem Project Data Synthesis Workshop. 19-20 March 2007. DFO Canadian Science Advisory Secretariat Proceedings Series 2007/028.

Gilmurray, M. C. and G. R. Daborn. 1981. Feeding relations of the Atlantic Silverside Menidia menidia in the Minas Basin, Bay of Fundy. Marine Ecology Progress Series 6: 231-235.

Gregory, R. S., V. Gotceitas, S. Fraser, P. Lundrigan, and J. A. Brown. 1997. Temporal and spatial survey of the fish community and its distribution among nearshore habitat types in the marine environment in the vicinity of Terra Nova National Park. Final Report to Canadian HeritageParks Canada. 125 pages.

Hanson, J. M., and S. C. Courtenay. 1995. Seasonal abundance and distribution of fishes in the Miramichi estuary.
Pages 141-160 in Water, science, and the public: the Miramichi Ecosystem. Edited by E. M. P. Chadwick. Canadian Special Publication of Fisheries and Aquatic Sciences. (123).

Hewitt, G. M. 2000. The genetic legacy of the Quaternary ice ages. Nature 405: 907-913.

Hooper, R. G., A. C. Mathieson, and R. T. Wilce. 2002. Geographic distributions of marine algae along the northeastern coast of North America. Pages 133-136 in NEAS Keys to Benthic Marine Algae of the Northeastern Coast of North America from Long Island Sound to the Strait of Belle Isle. Edited by J. R. Sears. NEAS, Dartmouth, Massachusetts.

Jessop, B. M. 1983. Aspects of the life history of the Atlantic silverside (Menidia menidia) of the Annapolis River, Nova Scotia. Canadian Manuscript Report of Fisheries and Aquatic Sciences (1694). 41 pages.

Johnson, M. S. 1974. Comparative geographic variation in Menidia. Evolution 28: 607-618.

Johnson, M. S. 1975. Biochemical systematics of the antherinid genus Menidia. Copeia 1975: 662-691.

Johnston, C. E., and M. Morse. 1988. Summer ichthyoplankton communities of two estuarine systems of Prince Edward Island. Canadian Journal of Zoology 66: 737-745.

Laurel, B. J., R. S. Gregory, and J. A. Brown. 2003. Settlement and distribution of age-0 juvenile cod, Gadus morhua and G. ogac, following a large-scale habitat manipulation. Marine Ecology Progress Series 262: 241-252.

Mahon, R., S. K. Brown, K. C. T. Zwanenburg, D. B. Atkinson, K. R. Buja, L. Claflin, G. D. Howell, M. E. Monaco, R. N. O'Boyle, and M. Sinclair. 1998. Assemblages and biogeography of demersal fishes of the east coast of North America. Canadian Journal of Fisheries and Aquatic Sciences 55: 1704-1738.

Markle, D. F., W. B. Scott, and A. C. Kohler. 1980. New and rare records of Canadian fishes and the influence of hydrography on resident and nonresident Scotian Shelf ichthyofauna. Canadian Journal of Fisheries and Aquatic Sciences 37: 49-65.

Mattila, J, G. Chaplin, M. R. Eilers, K. L. Heck Jr., J. P. O'Neal, and J. F. Valentine. 1999. Spatial and diurnal distribution of invertebrate and fish fauna of a Zostera marina bed and nearby unvegetated sediments in Damariscotta River, Maine (USA). Journal of Sea Research 41: 321-332.

McKenzie, R. A. 1959. Marine and freshwater fishes of the Miramichi River and estuary, New Brunswick. Journal of the Fisheries Research Board of Canada 16: 807-833.

Methven, D. A., R. L. Haedrich, and G. A. Rose. 2001. The fish assemblage of a Newfoundland estuary: diel, monthly and annual variation. Estuarine, Coastal and Shelf Science 52: 669-687.

Moring, J. R. 1990. Seasonal absence of fishes in tidepools of a boreal environment (Maine, USA). Hydrobiologia 194: 163-168.

Needler, A. W. H. 1940. A preliminary list of the fishes of Malpeque Bay. Proceedings of the Nova Scotia Institute of Science 1938-42, 20: 33-41.

O'Connor, S. E. 2008. Relationships between juvenile fish assemblages and the physical features of bays along the Atlantic coast of mainland Nova Scotia, with implications for coastal marine protected areas. M.Sc. thesis, Acadia University, Wolfville, Nova Scotia. 142 pages.

Rountree, R. A., and K. W. Able. 1992. Fauna of polyhaline subtidal marsh creeks in southern New Jersey: composition, abundance and biomass. Estuaries 15: 171-185. 
Scott, W. B., and E. J. Crossman. 1964. Fishes occurring in the fresh waters of insular Newfoundland. Department of Fisheries, Ottawa. 124 pages.

Scott, W. B., and M. G. Scott. 1988. Atlantic fishes of Canada. Canadian Bulletin of Fisheries Aquatic Sciences 219.

Squires, H. J. 1951. Appendix No. 26: New records of fishes from Newfoundland waters. Pages 38-39 in Report of the Newfoundland Fisheries Research Station for 1951. Edited by W. Templeman. Fisheries Research Board of Canada, St. John's, Newfoundland.

Squires, W. A., and S. W. Gorham. 1967. Silverside, Menidia menidia, and northern pipefish, Syngnathus fuscus, in the St. John River, N.B. Canadian Field-Naturalist 81: 280.

Steele, D. H. 1983. Marine ecology and zoogeography. Pages 421-465 in Biogeography and ecology of the island of Newfoundland. Edited by G. R. South. Dr. W. Junk Publishers, The Hague.

Templeman, W. 1966. Marine resources of Newfoundland. Fisheries Research Board of Canada Bulletin (154). Ottawa. 170 pages.

Thériault, M.-H., S. C. Courtenay, C. Godin and W. B. Ritchie. 2006. Evaluation of the Community Aquatic Moni- toring Program (CAMP) to assess the health of four coastal areas within the southern Gulf of St. Lawrence with special reference to the impacts of effluent from seafood processing plants. Canadian Technical Report of Fisheries and Aquatic Sciences Number 2649. 60 pages.

Thériault, M.-H., S. C. Courtenay, K. R. Munkittrick, and A. G. Chiasson. 2007. The effect of seafood processing plant effluent on sentinel fish species in coastal waters of the southern Gulf of St. Lawrence, New Brunswick. Water Quality Research Journal of Canada 42: 172-183.

Weinstein, M. P., S. L. Weiss, and M. F. Walters. 1980. Multiple determinants of community structure in shallow marsh habitats, Cape Fear River Estuary, North Carolina, USA. Marine Biology 58: 227-243.

Wroblewski, J. S., L. K. Kryger-Hann, D. A. Methven, and R. L. Haedrich. 2007. The fish fauna of Gilbert Bay, Labrador: a marine protected area in the Canadian subarctic coastal zone. Journal of the Marine Biological Association. U.K. 87: 575-587.

Received 22 October 2008

Accepted 19 October 2009 